\title{
EFFECT OF SURFACE TREATMENTS ON THE SPREADING VELOCITY OF SIMPLIFIED ADHESIVE SYSTEMS
}

\author{
EFEITO DE TRATAMENTOS DE SUPERFÍCIE NA VELOCIDADE DE ESCOAMENTO DE \\ SISTEMAS ADESIVOS SIMPLIFICADOS
}

Flávia B. PAZINATTO ${ }^{1}$, Fernanda A. LOPES ${ }^{2}$, Luiz MARQUEZINI JUNIOR ${ }^{1}$, Fabrício L. A. de CASTRO ${ }^{3}$, Maria Teresa ATTA ${ }^{4}$

1- DDS, MSc, PhD, Graduate student, Department of Operative Dentistry, Endodontics and Dental Materials, Bauru School of Dentistry, University of São Paulo, Bauru, São Paulo, Brazil.

2- Undergraduate student, Department of Operative Dentistry, Endodontics and Dental Materials, Bauru School of Dentistry, University of São Paulo, Bauru, São Paulo, Brazil.

3- DDS, MSc, PhD Assistant Professor, Department of Prevention and Oral Rehabilitation, School of Dentistry, Federal University of Goiás, Goiânia, Goiás, Brazil.

4- Associate Professor, Department of Operative Dentistry, Endodontics and Dental Materials, Bauru School of Dentistry, University of São Paulo, Bauru, São Paulo, Brazil.

Corresponding address: Maria Teresa ATTA - Al. Dr. Octavio Pinheiro Brisolla, 9-75, Bauru, SP, Brasil, 17012-901 / Fax: +55-14-32358325, Phone: + 55-14-3235-8358 - e-mail: tereatta@usp.br

Received: July 06, 2005 - Modification: September 15, 2006 - Accepted: November 06, 2006

\begin{abstract}
$O$

bjectives: To determine the roughness of glass surfaces submitted to different treatments and to correlate it with the spreading velocity of two adhesive systems. Materials and Methods: Glass slides were used as substrates to evaluate the spreading velocity of Single Bond and Prime \& Bond NT adhesive systems. Six different surface treatments were compared: 1) no treatment; 2) silanization (SL); 3) sandblasting (SB); 4) SB + SL; 5) 10\% hydrofluoric acid treatment (HF); 6) HF + SL. Before and after treatments, surface roughness was measured by a profilometer $(\mathrm{Ra}, \mu \mathrm{m})$. Drop volumes $(10 \mu \mathrm{l})$ of the adhesive systems were deposited onto substrates with a micropipette to observe materials spreading during 30s. Data were expressed in $\mathrm{mm} / \mathrm{s}$ as spreading velocity. Statistical significances among groups were analyzed using one-way and two-way-ANOVA designs and the SNK test. Results: Significant differences in spreading velocity were found between materials ( $\mathrm{p}<0.001)$ and among treatments $(\mathrm{p}<0.001)$. Silanization decreased the spreading velocity for both adhesives in comparison to groups where it was not performed $(\mathrm{p}<0.05)$. Differences in roughness were found only for SB surfaces that were rougher than the others $(p<0.05)$. Silanization decreased the roughness of SB surfaces $(p<0.05)$. Linear regression did not indicate any correlation between spreading velocity and roughness $(\mathrm{R}=0.173)$. Conclusions: Although surface treatments yielded different roughness, they did not provide differences in the spreading velocity of the simplified bonding systems studied. Silanization decreased bonding systems' spreading velocities. Uniterms: Ceramic; Sandblasting; Hydrofluoric acid; Roughness; Spreading velocity; Simplified adhesive system; Adhesion.
\end{abstract}

\section{RESUMO}

bjetivo: Determinar a rugosidade de superficies submetidas a diferentes tratamentos e correlacionar rugosidade com velocidade de escoamento de sistemas adesivos Material and Métodos: Lâminas de vidro foram utilizadas como substrato para avaliar a velocidade de escoamento dos sistemas adesivos Single Bond and Prime \& Bond NT. Seis diferentes tratamentos de superfície foram comparados: 1- sem tratamento; 2 - silanização (SL); 3 - jateamento (J); 4 - J + SL; 5 - condicionamento com ácido fluorídrico a 10\% (HF); 6 - HF + SL. Antes e após os tratamentos, foi mensurada a rugosidade das superficies (Ra, $\mu \mathrm{m})$. Gotas de $10 \mu \mathrm{l}$ de adesivo foram despositadas sobre as superficies e as velocidades de escoamento foram observadas durante $30 \mathrm{seg}$. Dados de velocidade de escoamento foram expressos em mm/ s. Significâncias estatísticas entre grupos foram analisadas pelos testes ANOVA (um e dois critérios) e SNK. Resultados: Houve diferenças significantes na velocidade de escoamento entre materiais $(\mathrm{p}<0.001)$ e entre tratamentos $(\mathrm{p}<0.001)$. Silanização diminuiu a velocidade de escoamento para ambos os adesivos em comparação aos grupos não silanizados $(\mathrm{p}<0.05)$. Houve diferença entre rugosidades inicial e final somente para o grupo jateado, que se apresentou como o mais rugoso $(\mathrm{p}<0.05)$. Silanização diminuiu a rugosidade das superficies jateadas $(\mathrm{p}<0.05)$. Regressão linear não indicou correlação entre velocidade de escoamento e rugosidade $(\mathrm{R}=0.173)$. Conclusões: Embora os tratamentos de superfície tenham produzido diferentes rugosidades, não produziram diferenças na velocidade de escoamento dos sistemas adesivos estudados. Silanização diminuiu a velocidade de escoamento dos sistemas adesivos.

Unitermos: Cerâmica; Jateamento; Ácido fluorídrico; Rugosidade; Velocidade de escoamento; Sistemas adesivos simplificados; Adesão. 


\section{INTRODUCTION}

Ceramics are, in many cases, the first choice materials for indirect restorations due to their biocompatibility with oral tissues as well as to their good esthetic properties ${ }^{28}$. However, it is also noticing that these materials commonly fail under function due to their brittle characteristics. A better adaptation between luting cements and ceramics can overcome the possibility of cohesive failures in the structure of the later, improving their stability in the oral environment ${ }^{28}$. Thus, it is necessary that luting cements present adequate mechanical properties to avoid postcementation failures, and, for this reason, the resin cements can be the best choice when compared to glass ionomer and zinc phosphate cements ${ }^{28}$.

Cementation using resin-based cements requires appropriate chemical or mechanical treatment of all substrates involved, i.e. enamel, dentin and dental porcelains, to allow bonding between teeth and indirect restorations. This bonding process is strongly dependent of some substrate characteristics like surface free energy and roughness as well as resin adhesive properties, such as surface tension and viscosity ${ }^{16}$. Mechanical or chemical surface treatments seem to raise facilities on the spreading of low viscous materials on a surface ${ }^{23}$ since they change substrate characteristics. Most of these treatments promote an increasing in porosity and roughness of dental ceramics, improving wettability. Rougher surfaces have wider contact areas available for bonding, and also provide an increased surface free energy in comparison to flatter or smoother ones $^{16,23}$. Therefore, a rough topography of a surface may facilitate adhesives' spreading and substrate's wettability ${ }^{16,22,23}$.

Some of the most used treatments to create physical modifications on ceramic surfaces are sandblasting ${ }^{22,23}$ and hydrofluoric acid etching ${ }^{9,22,23,28}$. Although these treatments may facilitate adhesion, their can also introduce defects on ceramics structures, which in turn can act as stress raisers, negatively affecting the material mechanical properties ${ }^{29}$. These defects can be produced by vestiges of the etching treatment ${ }^{9,23}$ or by microcracks created during sandblasting ${ }^{18,29,30}$. These events can compromise the integrity of a ceramic restoration submitted to masticatory forces $^{23}$ and their severity are dependent of the composition and the microstructure of each type of ceramic ${ }^{1}$. Removal of acids vestiges can be made using an ultrasonic bath ${ }^{9}$, as well as microporosities can be diminished by a silane plus an adhesive system application ${ }^{25}$. Silanization also allows a chemical adhesion between ceramics and resin cements, thus facilitating and improving bonding ${ }^{9,19,2125}$.

Several works have studied the principles of adhesion (surface free energy, contact angle, surface roughness and wettability) but there are few studies correlating adherends' roughness and adhesives flow capacity. Although the flow capacity cannot be directly correlated to wettability, it is quite important to understand how an adhesive spreads over an inclined surface once the clinical relevant surfaces are not totally flat. There are few studies that use, instead of water, a clinical relevant adhesive agent to measure contact angles or to evaluate wettability ${ }^{22}$. It is known that water creates lower contact angles with the surfaces than adhesive resins, wetting better the dental substrate ${ }^{22}$. Hence, it was decided to investigate an adhesive as the wetting agent and to verify its spreading ability over an inclined surface. In this research, the surface chosen to study the spreading phenomenon was a glass slide due to its low cost and $\mathrm{SiO}_{2}$ percentage content similar to that of some ceramics ${ }^{13}$. Glass slides have been also used to study the adhesion of silane coupling agents ${ }^{10}$.

The aim of this study was to determine the surface roughness created by different surface treatments and to correlate it with the spreading ability of two commercial adhesive systems, with or without previous surface silanization. The null hypotheses advanced here were: 1 ) there is no difference on the roughness created by different surface treatments; 2) there is no difference on the spreading velocity of different adhesive systems; 3) there is no difference on the spreading velocity of the adhesive systems over the surfaces when they are submitted to different treatments and 4) there is no correlation between surface roughness and adhesive systems spreading velocity.

\section{MATERIALS AND METHODS}

Surfaces of glass slides ( $25 \times 0.8 \times 1.1 \mathrm{~mm}$ ) (Corning, MX, Mexico) were used as substrates to evaluate the flow capacity of two adhesive systems (Single Bond, 3M ESPE

TABLE 1- Materials used in the study and their respective compositions and batch numbers

Material Composition

Batch Number

Single Bond BISGMA, HEMA, polyalkenoic acid copolymer, dimethacrylates, $1 \mathrm{FH}$

Prime \& Bond NT ethanol, water, camphorquinone

Di and tri-methacrylate resins (<10 wt \%), UDMA (<20 wt\%), PENTA (<10 wt\%), 0306000197 acetone, nanofillers (amorphous silicon dioxide), photoinitiators, stabilizers, cetylamine hydrofluoride

Hydrofluoric acid $10 \%$ hydrofluoric acid, water, thickening agent

Silane agent
112824 
Dental Products, St Paul, MN, USA and Prime \& Bond NT, Dentsply Ind. Com. Ltda, Petrópolis, RJ, Brazil) (Table 1), by means of spreading velocity measurements. The surfaces were previously treated with hydrofluoric acid or sandblasting, both with and without posterior silanization (Figure 1).

The groups treated with HF, a 10\% hydrofluoric acid gel (Dentsply Ind. Com. Ltda, Petrópolis, RJ, Brazil), were etched for 4 min and then rinsed with air/water spray for 30s. After rinsing, the specimens were cleaned for 1 min with distilled water in an ultrasonic bath (Ultrasonic Cleaner USC 700, Unique Ind. e Com. de Produtos Eletrônicos Ltda., Indaiatuba, SP, Brasil)[9]. The sandblasted groups were submitted to $50 \mathrm{~mm}$ aluminum oxide particles at $35 \mathrm{psi}$ and at a distance of $50 \mathrm{~mm}$ from the sandblaster nozzle tip (2 $\mathrm{mm}$ in diameter) until the surface exhibited an observable white opaque appearance ${ }^{22}$. Then, the glass slides were rinsed with air/water spray for $30 \mathrm{~s}$ and cleaned in the ultrasonic bath for 1 min $^{9}$.

Before and after surface treatments (one per glass slide), the surface roughness of each specimen was measured by means of a profilometer (Hommel Tester T1000, Hommelwerke GmbH, VS-Schwenningen, Germany). Five readings were made for each specimen and the $R a$ (arithmetic mean deviation of the roughness profile) was calculated in microns with a 4.8-mm cutoff value.

The spreading velocity of each adhesive system was measured on a surface inclination of $45^{\circ}$. This was performed using a protractor and a base to support the glass slides. A metallic millimeter ruler was put on the back of each glass slide to allow measurements of the distance traveled by the adhesive systems during their flowing.

For some groups, a silane agent (Silano Agente de União, Dentsply Ind. Com. Ltda, Petrópolis, RJ, Brazil) was applied twice over the glass slide with a microbrush for $15 \mathrm{~s}$ and dried, following the manufactures' instructions. Drop volumes of $10 \mu \mathrm{l}$ from each adhesive system were placed over the glass slides with a micropipette (Pipetman, Gilson
Medical Electronics S.A., France) and the spreading of each drop was observed for $30 \mathrm{~s}$, and reported as millimeters per second $(\mathrm{mm} / \mathrm{s})$. Measurements were performed five times in each individual glass slide, according to the surface treatment protocol established for each group. The measurements were made after the glass slides had been cleaned with household detergent, to avoid a greasy surface. After that and before each measurement, an acetone-soaked gauze was used to remove vestiges of adhesive systems, and then the glass slide surface was air-blow dried. Acetone was used to remove silane and adhesive from the surfaces as it apparently does not influence bonding ${ }^{7}$, thus not interfering with the measurements. The experiments were carried out at both controlled room temperature $\left(25 \pm 1{ }^{\circ} \mathrm{C}\right)$ and relative humidity (50 $\pm 5 \%)$.

Data were analyzed by a two-way ANOVA design, considering materials and surface treatments as independent variables. To compare roughness from all groups, a oneway ANOVA test was used. Multiple post hoc comparisons were performed using the Student-Neulman-Keuls test (SNK). Linear regression was applied to observe the existence of a possible interaction between spreading velocity and roughness. Statistical significance was stated at a confidence level of $95 \%$ for all analyses.

\section{RESULTS}

Regarding spreading velocity, the two-way ANOVA test indicated statistically significant differences between adhesive materials ( $\mathrm{p}<0.001)$ as well between treatments ( $\mathrm{p}$ $<0.001$ ) (Table 2). No significant differences were found among groups when the interaction between materials and treatments was considered $(\mathrm{p}=0.097)$. SNK test showed that Single Bond presented a lower spreading velocity than did Prime \& Bond NT, irrespective of the surface treatment employed $(p<0.05)$. Silanization decreased spreading velocity means for both adhesive systems tested $(\mathrm{p}<0.05)$.

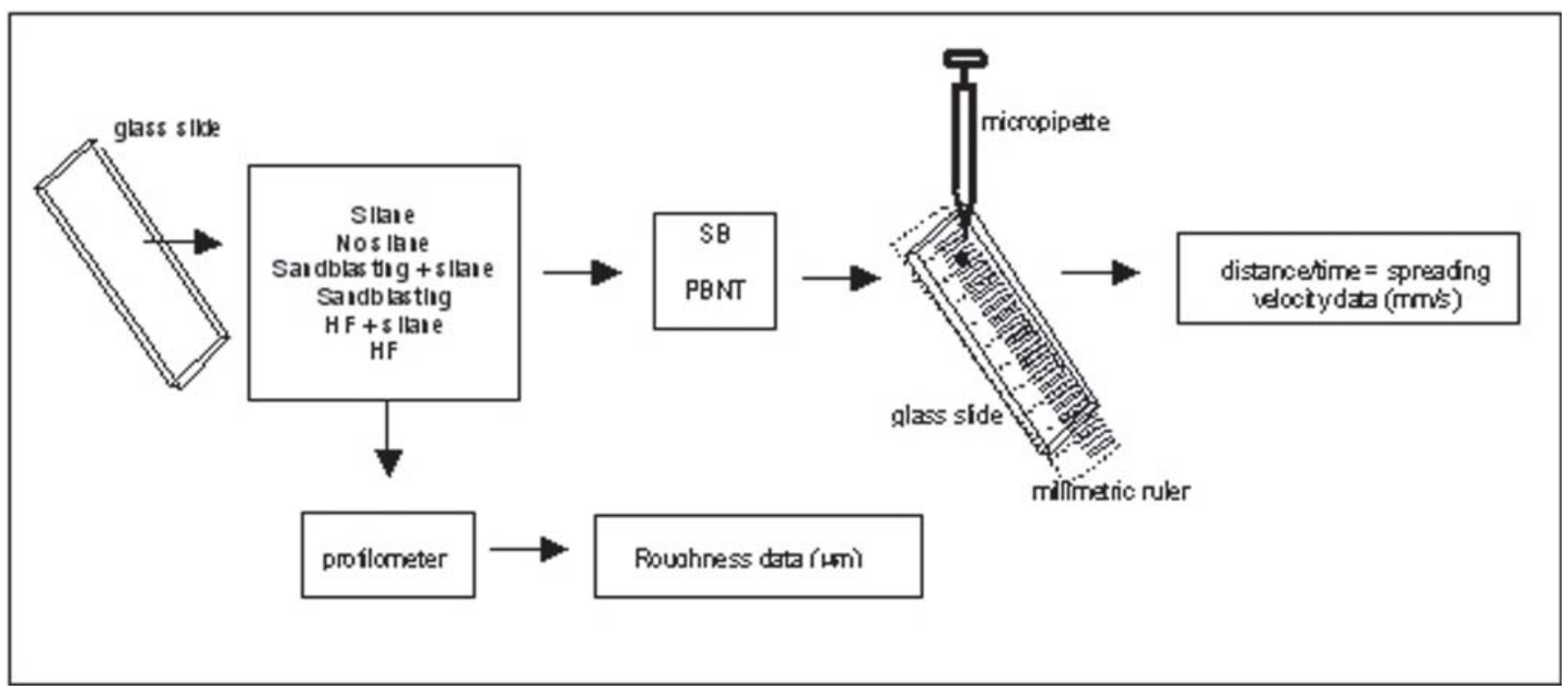

FIGURE 1- Scheme of study groups and experimental conditions 
The one-way ANOVA test indicated statistically significant differences between surface treatments employed when roughness was considered as the testing variable (p $<0.05$ ) (Table 3). The post-hoc test showed that rougher surfaces were found only when sandblasting was employed $(\mathrm{p}<0.05)$. Silanization decreased surface roughness of sandblasted surfaces $(\mathrm{p}<0.05)$, but these surfaces still remained rougher than the non-sandblasted ones. Any difference in roughness was found among untreated, silanated, etched and etched/silanated surfaces ( $p>0.05$ ).

Linear regression did not indicate any interaction between spreading velocity and roughness $(\mathrm{R}=0.173$; $\mathrm{Rsqr}=0.0299)$.

\section{DISCUSSION}

The selection of glass slides as substrates for the measurement of both adhesive spreading velocity and surface roughness was due to their low cost, compared to dental ceramics, and also by they vitreous composition $\left(\mathrm{SiO}_{2}\right)$, similar to that found in feldspathic porcelains ${ }^{13}$. Glass has been already used to study silane adhesion ${ }^{10}$.

According to the adhesion principles, adherend surface free energy and roughness as well adhesive surface tension and viscosity may influence wettability ${ }^{16}$. Although wettability cannot be directly correlated to spreading velocity, it is supposed that higher spreading velocities yield better wettabilities.

Even though adhesive resins are the most clinically relevant agents to measure contact angles (considering adhesive restorations), studies have been frequently using water for this purpose instead of them ${ }^{22}$. However, resins yield higher mean contact angles than water, and therefore do not wet ceramics as well as water ${ }^{22}$.

According to the results found here, the mean spreading velocity found for Single Bond was significantly lower than that of Prime \& Bond NT, regardless of the surface treatment used. Different types and rates of monomers mixtures lead to different materials viscosities ${ }^{4,12,27}$. Although we did not measure the viscosity of the adhesives employed in this study, we can assume, based on the composition of each material, that Single Bond presents a higher viscosity than Prime \& Bond $\mathrm{NT}^{12,27}$. Single Bond contains $60-70 \mathrm{wt} \%$ of BIS-GMA in its composition (Table 1), which can significantly increase its viscosity. BIS-GMA is a very viscous substance because it has a high molecular weight, it has a large rigid section, and it is capable of hydrogen bonding to its neighbors due to the presence of the hydroxyl group and carbonyl oxygen ${ }^{11}$. More viscous adhesives do not wet well a substrate as do less viscous ones ${ }^{17}$. Also, the substrate chemical composition and the adhesive complex monomeric mixture influence respectively surface free energy and surface tension ${ }^{16}$, consequently affecting wettability and the time required to spreading ${ }^{24}$. Once the substrates had the same origin and composition, i.e. glass slides, for all groups, it can be inferred that the surfaces tensions of the adhesive systems used are different, providing more or less wettability, in compliance with other results ${ }^{5}$.

Surface treatments can modify both surface free energy and roughness of a solid ${ }^{16}$ increasing or decreasing adhesives wettability over it. Theoretically, different surface treatments create different surface free energies and roughness, and therefore promote distinct adhesive wettabilities. In this study we found that the untreated, sandblasted or etched surfaces allowed adhesives to spread at similar velocities, being the spreading velocity affected only when these surfaces were silanated. Indeed, silane application decreased the mean spreading velocity of the adhesives tested $(\mathrm{p}<0.05)$. This decreasing can be due to the chemical interaction between silane and adhesive. As silane is a bi-functional coupling agent, it can attach with both inorganic (glass slide) and organic substrates

TABLE 2- Mean spreading velocity values of adhesive systems for each surface treatment, expressed in $\mathrm{mm} / \mathrm{s}(\mathrm{sd})(\mathrm{n}=5)$ Mean values with the same letters (capital letter - column, lower case - line) are not statistically significantly different ( $p$ > 0.05)

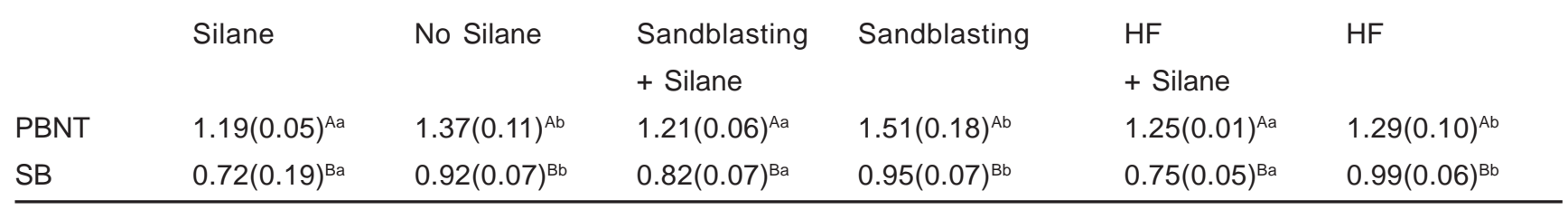

TABLE 3- Mean roughness values (Ra) before and after surface treatments, expressed in $\mu \mathrm{m}(\mathrm{sd})(\mathrm{n}=5)$ Mean values with the same letters are not statistically significantly different $(p>0.05)$

\begin{tabular}{lllllll} 
Treatments & None & Silane & Sandblasting & $\begin{array}{l}\text { Sandblasting } \\
+ \text { silane }\end{array}$ & HF & $\begin{array}{l}\text { FF } \\
+ \text { silane }\end{array}$ \\
\hline $\mathrm{Ra}$ & $0.01(0.001)^{\mathrm{a}}$ & $0.01(0.0008)^{\mathrm{a}}$ & $0.78(0.11)^{\mathrm{b}}$ & $0.58(0.28)^{\mathrm{c}}$ & $0.06(0.01)^{\mathrm{a}}$ & $0.05(0.007)^{\mathrm{a}}$ \\
\hline
\end{tabular}


(adhesive). Thus, silane probably modified the surface free energy of the substrate, negatively influencing adhesives spreading velocities. Conversely to our belief, it should facilitate the wettability and do not raise difficulties to adhesive spreading, as was observed here. Perhaps, at least, more time will be necessary for an adhesive to spread and properly wet a ceramic surface. Further investigations should be done to clarify this subject.

Adhesion is somewhat dependent on the substrate roughness. It can be improved when occurring over rougher surfaces because these surfaces present a larger contact area available for bonding ${ }^{22,23}$. Unlike this, rougher surfaces may challenge a liquid wettability since they can entrap air inside of their own irregularities, reducing the total area available for bonding ${ }^{11}$. We can also hypothesize that both situations are prone to happen at the same time, leading to no roughness effect on bonding. So, it is not surprising that some authors have not found any correlation between roughness and wettability ${ }^{2}$. Our results corroborate those findings since we did not observe any correlation between roughness and spreading velocity, considering the surface treatment protocols adopted here and the limitations of this work. Nevertheless, apart from the roughness parameter to influence wettability and spreading, each surface treatment tested may have created, besides roughness, chemical modifications on the subsurface of the substrate, thereby providing dissimilar surface free energies of the glass slide. It can be inferred since the external surface free energy of a solid is higher than the internal free energy ${ }^{3}$, and, probably, the lower free energy of treated surface may have influenced on the spreading velocities more than roughness.

As expected, sandblasted surfaces were rougher than the other ones. Whereas sandblasting created more roughness, the spreading velocity values observed for these rougher surfaces were not different from those found in the etched and unetched ones without silanization ( $p>0.05)$, suggesting that all of them have similar wettabilities. Moreover, it has been suggested that if a surface is too much rough it can avoid an adequate adhesive spreading ${ }^{16}$. It is also known that sandblasting creates microcracks, damaging the ceramic surface ${ }^{23,29}$. Nevertheless, grooves and porosities found in sandblasted ceramics surfaces cannot be considered the only factors responsible to worsen ceramic's flexural resistance, as this property is highly dependent on the specific composition and microstructure of each material ${ }^{1}$. Hence, sandblasting should not be recommended to increase wettability and adhesion, at least from the standpoint of an adherend/adhesive surface interaction. Some authors are in compliance with the little benefit of sandblasting to the adhesion ${ }^{26}$.

Hydrofluoric acid did not yield a statistically significant increase in the measured roughness. The lower roughness of the HF etched surfaces can be due to the formation of insoluble silica salts on the glass slide surface similar to what happens in ceramics ${ }^{6,9}$. The use of an ultrasonic bath for 1 minute probably did not remove these insoluble precipitates. Differences in ceramics microstructure and composition can affect the micromechanical retention created by etchant solutions ${ }^{13,15,19}$, and this may explain the restrict roughness reached by hydrofluoric acid. Acid etching has a limited influence on the surface free energy of ceramics and it is necessary to silanate these etched surfaces to get adhesion improved ${ }^{20}$. Silanization increases the adhesive strength of ceramics to dental tissues, regardless of the material composition or acid etching ${ }^{15}$. Therefore, due to the inadequate surface characterization reached by $\mathrm{HF}$ in this study due to a similar roughness found in etched and unetched surfaces, from the standpoint of adhesive strength, it is suggested that silanization alone should be enough to improve adhesion ${ }^{8,14,19,26}$. More research is need in this area.

Silanization statistically decreased the roughness of sandblasted surfaces, but the same effect was not found in other groups. We suggest that silane penetrated into the more pronounced irregularities created by sandblasting, minimizing their magnitude. However, silanization was not enough to reduce the roughness of sandblasted surfaces to the levels found in the non-sandblasted ones, confirming that sandblasting can create too much roughness on a glass surface. Nevertheless, even this not so pronounced "smoothing effect" of silanization can be capable to reinforce ceramics structure. Most researches on ceramic area have studied tensile strength ${ }^{21}$ or flexural strength after treatments and silanization. The explanation for the improvement in these mechanical properties after silanization can be related to two aspects, the possibility of silane to fill the irregularities created by surface treatments ${ }^{9,21}$, and by its chemical adhesion with the substrate, i.e. adhesive/resinous cement/ ceramic $^{29}$.

In accordance with the hypotheses tested previously to this study and based on the results found here, we reject the null hypotheses 1, 2 and 3, i.e., there was a significant difference on the surface roughness obtained from the different surface treatments; there was a significant difference in the spreading velocity of the adhesives tested and there was a significant difference in the spreading velocity of both adhesives over the surfaces submitted to different treatments. We accept the null hypothesis 4 since no correlation between spreading velocity and surface roughness was found. These findings suggest that more research is needed to understand the role of surface treatments on adhesion as well on the stability of dental porcelain, when current adhesive systems are employed.

\section{CONCLUSION}

Within the limitations of this study, the real need to treat a surface (e.g., sandblasting, HF) of a glass restorative substrate (ceramic) prior to adhesive procedures may be questioned, at least from the standpoint of wetting. Although surface treatments yielded different roughness, they did not provide differences in the spreading velocity of the simplified bonding systems studied. Silanization decreased bonding systems' spreading velocities, so it may raise difficulties for an adhesive to properly wet a substrate, thus adversely affecting bonding. 


\section{ACKNOWLEDGMENTS}

This study was partially supported by CAPES and FAPESP(\#03/11721-9), Brazil.

\section{REFERENCES}

1- Albakry M, Guazzato M, Swain MV. Effect of sandblasting, grinding, polishing and glazing on the flexural strength of two pressable allceramic dental materials. J Dent. 2004;32:91-9.

2- Al-Omari WM, Mitchell CA, Cunningham JL. Surface roughness and wettability of enamel and dentine surfaces prepared with different dental burs. J Oral Rehabil. 2001;28:645-50.

3- Anusavice KJ. Estrutura da matéria e princípios de adesão. In: Anusavice KJ. Phillips: materiais dentários. Rio de Janeiro: Elsevier; 2005. p. 19-37.

4- Asmussen E. Penetration of restorative resins into acid etched enamel I. Acta Odontol Scand. 1977;35:175-82.

5- Asmussen E, Peutzfeldt A. Surface energy characteristics of adhesive monomers. Dent Mater. 1998;14:21-8.

6- Bailey LF, Bennett RJ. Dicor surface treatments for enhanced bonding. J Dent Res. 1982;67:925-31.

7- Barghi N, Chung K, Farshchian F, Berry T. Effects of the solvents on bond strength of resin bonded porcelain. J Oral Rehab. 1999;26:853-7.

8- Barghi N. To silanate or not to silanate: making a clinical decision. Compendium. 2000;21:659-62.

9- Canay S, Hersek N, Ertan A. Effect of different acid treatments on a porcelain surface. J Oral Rehabil. 2001;28:95-101.

10- Chen TM, Brauer GM. Solvent effects on bonding organo-silane to silica surfaces. J Dent Res. 1982;61:1439-43.

11- Darvel BW. Surfaces. In: Darvell BW. Materials Science for Dentistry. Hong Kong: BW Darvell; 2002. p. 212-32.

12- Davy KWM, Kalachandra S, Pandain MS, Braden M. Relationship between composite matrix molecular structure and properties. Biomaterials. 1998;19:2007-14.

13- Della Bonna A, Anusavice KJ. Microstructure, composition and etching topography of dental ceramics. Int J Prosthodont. 2002;15:159-67.

14- Della Bonna A, Anusavice KJ, Hood JAA. Effect of ceramic surface treatment on tensile bond strength to a resin cement. Int J Prosthodont. 2002;15:248-53.

15- Della Bonna A, Anusavice KJ, Mecholsky JJ Jr. Failure analysis of resin composite bonded to ceramic. Dent Mater. 2003;19:693-9.

16- Eick JD, Johnson LN, Fromer JR, Good RJ, Neumann AW. Surface Topography: Its influence on wetting and adhesion in a dental adhesive system. J Dent Res. 1972;51:780-8.

17- Hisamatsu N, Atsuta M, Matsumura H. Effect of silane primers and unfilled resin bonding agents on repair bond of a prosthodontic microfilled composite. J Oral Rehabil. 2002;29:644-8.

18- Jager N, Feilzer AJ, Davidson CL. The influence of surface roughness on porcelain strength. Dent Mater. 2000;16:381-8.
19- Jardel V, Degrange M, Picard B, Derrien G. Correlation of topography to bond strength of etched ceramic. Int J Prosthodont. 1999;12:59-64.

20- Jardel V, Degrange M, Picard B, Derrien G. Surface energy of etched ceramic. Int J Prosthodont. 1999;12:415-8.

21- Lu R, Harcourt JK, Tyas MJ, Alexander B. An investigation of the composite resin/interface. Aust Dent J. 1992;37:12-9.

22- Oh WS, Shen C, Alegre B, Anusavice KJ. Wetting characteristic of ceramic to water and adhesive resin. J Prosthet Dent. 2002;88:61621

23- Phoenix RD, Shen C. Characterization of treated porcelain surfaces via dynamic contact angle analysis. Int J Prosthodont. 1995;8:187-94.

24- Rosales-Leal JI, Osorio R, Holgado-Terriza JA, Cabrerizo-Vilchez MA, Toledano M. Dentin wetting by four adhesive systems. Dent Mater. 2001;17:526-32.

25- Rosenstiel SF, Gupta PK, Van der Sluys RA, Zimmerman MH. Strength of a dental glass ceramic after surface coating. Dent Mater. 1993;27:274-9.

26- Shahverdi S, Canay S, Sahin E, Bilge A. Effect of different surface treatment methods on the bond strength of composite resin to porcelain. J Oral Rehabil. 1998;25:699-705.

27- Silikas N, Watts DC. Rheology of urethane dimethacrylate and diluent formulations. Dent Mater. 1999;15:257-61.

28- Thompson JY, Rapp MM, Parker AJ. Microscopic and energy dispersive $\mathrm{X}$-ray analysis of surface adaptation of dental cements to dental ceramic surfaces. J Prosthet Dent. 1998;79:378-83.

29- Thompson VP, Rekow DE. Dental ceramics and the molar crown testing ground. J Appl Oral Sci. 2004;12:26-36.

30- Wolf DM, Powers JM, O’Keefe KL. Bond strength of composite to etched and sandblasted porcelain. Am J Dent. 1993;6:155-8. 